\title{
Efecto de un polímero natural biodegradable en las propiedades de morteros de cal en estado endurecido
}

\section{Effect of a biodegradable natural polymer on the properties of hardened lime-based mortars}

\author{
A. Izaguirre(*), J. Lanas ${ }^{(* *)}, \underline{\text { J. I. Álvarez }}{ }^{(*)}$
}

Recepción/Received: 30-X-09

Aceptación/Accepted: 22-III-10

Publicado online/Online publishing: 31-III-10

RESUMEN

Como alternativa a los materiales con base cemento y a plastificantes obtenidos por vía química, se estudió el efecto de un almidón comercial incorporado a morteros de cal aérea. Se ensayaron dosificaciones diferentes para analizar su influencia sobre las propiedades del material. En los morteros se determinaron densidad, retracción, absorción de agua por capilaridad, permeabilidad, resistencias mecánicas, porosidad, distribución de tamaños de poro y durabilidad frente a ciclos de hielo-deshielo. El almidón actuó como espesante hasta la dosis de 0,30\%, pero cambió al añadirlo en la dosis más alta (0,50\%): en este caso, se comportó como un plastificante, dispersando la cal a través de la mezcla en fresco, dando lugar a un material más trabajable. Como resultado, en la dosis $0,50 \%$, la matriz del mortero endurecido presentó gran coherencia, por su mayor densidad y menor porosidad, lo que implicó una menor capilaridad y permeabilidad, mejores resistencias mecánicas y durabilidad.

Palabras clave: mortero de cal, polímero, propiedades mecánicas, porosimetría de mercurio, durabilidad.
SUMMARY

As an environmentally friendly and energy-saving alternative to cement-based materials and to some chemically obtained water-reducers, a commercialized starch was incorporated into aerial lime-based matrix. Different dosages were tested in order to study the influence that the amount of additive exerted on the properties of the material. Density, shrinkage, water absorption through capillarity, water vapour permeability, mechanical strengths, porosity, pore size distribution, and durability in the face of freezing-thawing cycles were studied in the mortars. The tested starch acted as a thickener for dosages up to $0.30 \%$, and changed its behaviour for the largest dosage (0.50\%): in that case it behaved as a plasticizer, dispersing the lime through the fresh mass and generating a more workable material. As a result, the matrix of the hardened mortar presented great coherence, owing to its large density and low porosity, characteristics which led to lower capillarity and permeability, better mechanical properties and durability.

Keywords: lime mortar, polymer, mechanical properties, mercury porosimetry, durability.

\footnotetext{
(*) Universidad de Navarra (Pamplona, España).

(**) CTH Navarra (Tajonar, España).
} 


\section{INTRODUCCIÓN}

La restauración y mantenimiento de edificios históricos ha sido destacada como vía para la protección del medio-ambiente además de como salvaguarda del Patrimonio Cultural (1). Para el éxito de un proceso de restauración resulta crítica la elección de un mortero de reparación adecuado, dado que la compatibilidad entre los materiales originales y los nuevos es de especial importancia $(2,3)$. Hasta la aparición del cemento (a mediados del siglo XIX), la cal era el conglomerante más empleado en construcción, por lo que los materiales basados en ella constituyen la mejor opción para los trabajos de restauración $(1,2)$.

Además, el uso de morteros de cal es una alternativa más respetuosa con el medio ambiente (4), no ya sólo para procesos de restauración sino también para nuevos enlucidos y revocos. La producción de cemento requiere temperaturas cercanas a los $1.450{ }^{\circ} \mathrm{C}(5)$, mientras que la cal se obtiene a partir de roca caliza a ca. $900^{\circ} \mathrm{C}$ $(6,7)$. El menor consumo de energía junto a la reducción en las emisiones de contaminantes atmosféricos procedentes del proceso de combustión hacen de la cal un material más respetuoso con el medio ambiente que el cemento.

Se han realizado trabajos de investigación previos enfocados hacia el efecto de almidones y sus derivados en materiales con base cemento, ya que aquéllos pueden actuar como aditivos modificadores de la reología (8-15). Estos aditivos han actuado como espesantes (9) y como reductores de agua (10-15). El uso de almidones como reductores de agua podría ser de especial interés, dado que son biodegradables y pueden ser incorporados en las mezclas en lugar de condensados de formaldehído-sulfonato de naftaleno (FDN) o plastificantes tipo policarboxilato (PC). La adición de almidones contribuiría, por lo tanto, a reducir los problemas medioambientales $(10,13)$.

En relación con el mecanismo de acción de los aditivos, se han publicado diversos factores que afectan a la influencia que un polímero ejerce sobre una mezcla, como: a) el tipo y propiedades de conglomerante; b) la cantidad de agua de amasado; c) el proceso de amasado; d) los procedimientos experimentales y e) la presencia y propiedades de aditivos (16). Todos estos factores apuntan hacia la dificultad en predecir el comportamiento de los almidones.

El peso molecular de un almidón concreto o de alguno de sus derivados parece ser determinante para su comportamiento: polímeros de alto peso molecular tienden a aglomerarse y a producir un efecto espesante en los morteros, mientras que derivados de bajo peso molecular pueden ser fácilmente adsorbidos sobre la superficie de las partículas

\section{INTRODUCTION}

Restoration and maintenance of historic buildings has been reported to be a way to protect the environment as well as safeguard our Cultural Heritage (1). An adequate choice of repair mortars is critical for the success of a restoration process, as the compatibility between the original materials and the new ones is essential $(2,3)$. Until the appearance of cement (in the mid-19th century), lime was the most widely used binder in construction, so lime-based materials constitute the best option for restoration work $(1,2)$.

Furthermore, the use of lime-based mortars is an environmentally friendly alternative (4), not only for restoration work but also for new renders and grouts. The production of cement requires temperatures around $1450^{\circ} \mathrm{C}(5)$, while lime is obtained from calcareous stone at ca. $900^{\circ} \mathrm{C}(6,7)$. The lower energy consumption, together with a reduction in the emission of airpollutants from the combustion process, makes the lime a more environmentally friendly product compared to cement.

Previous research has focused on the effect of starches and starch derivatives in cement-based materials, as they can act as rheology-modifying admixtures (8-15). They have been shown to act as thicknening agents (9) and also as water-reducers (10-15). The use of starches as water-reducing agents could be especially desirable, as they are biodegradable and can be incorporated in the mixtures instead of conventional naphthalene sulphonated formaldehyde condensates (FDN) or polycarboxylate $(P C)$-type plasticizers. The addition of starches therefore contributes to reducing the environmental problems $(10,13)$.

Regarding the action mechanism of additives, many factors affecting the influence that a polymer exerts on a mixture have been reported, such as: a) the type and properties of the binder; $b$ ) the amount of mixing water; c) the mixing process; d) the experimental procedures and e) the presence and properties of additives (16). All these factors point to the difficulty of predicting the behaviour of the starches.

The molecular weight of a starch or any of its derivatives seems to be a critical point affecting its behaviour: high molecular weight polymers tend to agglomerate and produce a thickening effect on the mortars, while low molecular weight derivatives can easily be adsorbed on the binder particles' surface, generating steric repulsions 
de conglomerante, dando lugar a repulsiones estéricas (esto es, un efecto dispersante) que conduce a viscosidades más bajas $(13,15)$.

Teniendo como base la similitud entre almidones y derivados celulósicos se han dilucidado y ensayado diversos efectos de los almidones, tales como:

a) comportamiento espesante, que permite la utilización de almidones como aditivos mejoradores de la viscosidad (9);

b) estrechamente relacionado con ello, un efecto retenedor de agua, debido a que estos aditivos -con grupos funcionales hidrofílicos - son capaces de fijar agua en su estructura, reduciendo la cantidad de agua libre en la mezcla y produciendo un incremento en la viscosidad. Además, las cadenas laterales de estas moléculas pueden interaccionar entre sí, contribuyendo a ulteriores aumentos de la viscosidad (17);

c) capacidad retardadora del fraguado (18), si bien el mecanismo de acción de este proceso hasta el momento no se ha aclarado completamente (19-21);

d) un efecto dispersante sobre las partículas de cemento, i.e. comportamiento como plastificante (10-15). En ese sentido, se han señalado muchas ventajas relativas al uso de éteres de almidón como reductores de agua (en lugar de FDN o plastificantes tipo policarboxilato): reducción de problemas medioambientales $(10,13)$, acción reductora de agua más intensa (13) ya que el principal mecanismo de dispersión es una fuerte repulsión estérica (11), y mejores propiedades reológicas de las pastas de cemento (13).

Como consecuencia del creciente interés en morteros de cal antes mencionado (1-3), se han publicado diversos trabajos de investigación sobre el comportamiento de morteros de cal, en general, como los artículos de Lanas et al. $(2,22,23)$, Arandigoyen et al. (24-26) y Rodríguez-Navarro et al. (27). Más recientemente se ha publicado el comportamiento de morteros de cal modificados con distinto tipo de aditivos: Izaguirre et al. han descrito el comportamiento de morteros de cal con hidrofugantes (28) y varios aspectos concernientes a la durabilidad de morteros de cal modificados por diferentes aditivos (29). En relación al empleo de agentes retenedores de agua y plastificantes, Seabra et al. (30) han concluido que la HPMC ejerce inicialmente un efecto espesante sobre las mezclas pero que, tras algún tiempo de agitación, la tendencia se invierte por la excesiva entrada de aire. Estos autores también han incorporado un superplastificante, formaldehído-sulfonato de melamina, a las mezclas, encontrando un incremento en los valores inicial y final del flujo en la mesa de sacudidas, un considerable aumento en límite de fluidez y un descenso en el valor del torque de los morteros (30). (i.e. a dispersing effect) which lead to lower viscosities $(13,15)$.

On the basis of the similarity between starches and cellulose derivatives, several effects of the starches have been clarified and tested, such as:

a) thickening behaviour, which allows use of starches as viscosity enhancing admixtures (VEA's) (9);

b) closely related to this, a water-retaining effect, because these additives - with functional hydrophilic groups - are able to fix water in their structure, reducing the amount of free water in the mixture and producing an increase in viscosity. Furthermore, their lateral chains can suffer an intertwining process that contributes to further increase the viscosity (17);

c) a set-retarding ability (18), even though the action mechanism of this process has so far not been fully clarified (19-21);

d) a dispersing effect on the cement particles, i.e. a plasticizing behaviour (10-15). Many advantages regarding the use of starch ethers as water-reducing agents (instead of FDN or PC plasticizers) have been stated: reduction of environmental problems (10, 13), a more powerful water-reducing action (13) because a strong steric hindrance is the main dispersing mechanism (11), and better rheological properties of cement pastes (13).

As a result of the abovementioned increasing interest in lime mortars (1-3), several pieces of research have addressed the behaviour of these lime mortars, in general, such as the works by Lanas et al. (2, 22, 23), Arandigoyen et al. (24-26), Rodriguez-Navarro et al. (27). More recently, the performance of lime mortars modified with different kind of additives has received attention: Izaguirre et al. reported the behaviour of lime mortars with water-repelling agents (28) and several aspects on the durability of lime mortars modified with different additives (29). On the use water-retaining agents and plasticizers Seabra et al. (30) concluded that HPMC initially exerted a thickening effect on the mixtures but, after some shaking time, this tendency was reversed, due to excessive entry of air. They also incorporated a sulphonated melamine formaldehyde superplasticizer to the mixtures, reporting an increase in the initial and final slump, a considerable increase in the yield stress and a decrease in the torque value of the mortars (30). Fortes-Revilla et al. (31) incorporated a polycarboxylate polyoxyethylene 
Fortes-Revilla et al. (31) han incorporado un polioxietileno de policarboxilato a un mortero de cal apagada-metacaolín, encontrando una reducción en el tiempo de fraguado y unas resistencias mecánicas máximas superiores y alcanzadas más rápidamente.

Sin embargo, no hay trabajos publicados sobre el comportamiento de morteros de cal modificados por la adición de almidón. Los efectos espesante y dispersante del almidón antes comentados muestran comportamientos antagónicos fuertemente dosis-dependientes, como se ha publicado en un trabajo anterior que nuestro grupo de investigación ha llevado a cabo para investigar el efecto de la adición de almidón sobre las propiedades reológicas de morteros de cal (32). En ese trabajo se ha reflejado cómo el efecto espesante se debe a que las moléculas del polímero se adsorben sobre las partículas de cal, actuando como floculantes, y se ha confirmado a través de los resultados de potencial zeta y de distribución de tamaño de partículas. Para mayores cantidades de polímero han aparecido fuerzas de repulsión estérica y electrostática, involucrando, consiguientemente, un mecanismo de dispersión que explica el efecto plastificante así como el comportamiento del mortero en estado fresco. Este estudio se centra en el efecto de la adición de un almidón sobre las propiedades de una matriz de cal endurecida. Se han evaluado el comportamiento del almidón y la influencia de las diferentes dosificaciones mediante análisis de densidad, retracción, absorción de agua por capilaridad, permeabilidad al vapor de agua y resistencias mecánicas. Se ha analizado la influencia de la incorporación del almidón sobre la microestructura de la matriz mediante la distribución de tamaño de poro obtenida por porosimetría de intrusión de mercurio. Los estudios de durabilidad (ciclos de hielo-deshielo) permitirán extraer conclusiones sobre la mejora introducida en los morteros de cal por la adición de almidón. El empleo de un mortero de cal así modificado debe ser una opción valiosa a considerar teniendo en cuenta la perspectiva medioambiental, ya que a) la cal resulta ser un conglomerante de bajo coste (en términos de consumo energético y emisión de contaminantes) y más adecuado para trabajos de restauración, y b) el almidón es un polímero natural y biodegradable, lo que presenta evidentes ventajas frente a otros reductores de agua.

\section{MATERIALES Y MÉTODOS}

\subsection{Materiales}

Para la preparación de los morteros se utilizaron una cal aérea comercial y un árido calizo de gran pureza. La cal -clase CL 90-S de acuerdo a la normativa española (33) - la suministró Calinsa (Navarra). El árido procedió de Caleras de Liskar (grupo HORPASA), de naturaleza caliza. Las características de los materiales empleados así in a slaked lime-metakaolin mortar, and found a setting time reduction and larger, quicker maximum mechanical strengths.

Nevertheless, there is a gap in the literature concerning the behaviour of lime-based materials modified by starch addition. The thickening and dispersing effects of the starch mentioned above show conflicting behaviours that were reported to be strongly dose-dependent in a previous paper by our research group designed to investigate the effect of starch addition on the rheological properties of lime mortars (32). In the abovementioned work, it was reported that the thickening effect took place because polymer molecules were adsorbed onto lime particles acting as a flocculant, as could be confirmed by zeta-potential and particle size distribution results. For large amounts of polymer, steric hindrance and electrostatic repulsive forces appeared, leading to a dispersion mechanism which explained the plasticizing effect as well as the fresh mortar behaviour. The present study therefore focuses on the effect of a starch addition on the properties of a hardened lime matrix. The performance of the starch as well as the influence of the different dosages is evaluated by conducting analyses of density, shrinkage, water absorption capacity through capillarity, water vapour permeability and mechanical strengths. Any influence of the starch addition on the microstructure of the matrix has been assessed by means of pore size distribution obtained from mercury intrusion porosimetry data. Durability studies (freezing-thawing cycles) will also allow to draw conclusions about the enhancement of lime-based mortars through starch addition. The use of such a modified mortar would be a valuable option taking into account the environmental perspective, because a) lime turns out to be a low-cost binder (in terms of energy consumption and pollutants emission) and more suitable for repair work, and b) starch is a natural, biodegradable polymer, and thus has clear advantages over other water-reducers.

\section{MATERIALS AND METHODS}

\subsection{Materials}

An aerial commercial lime and a pure limestone aggregate were used to prepare the mortars. The lime class CL 90-S according to Spanish standard (33)- was supplied by Calinsa (Navarra). The aggregate was supplied by Caleras de Liskar (grupo HORPASA), and was a calcareous type. The characteristics of the materials 
como de su granulometría se han publicado previamente (28). Los morteros se prepararon mezclando $341,7 \mathrm{~g}$ de cal y $1.286,9 \mathrm{~g}$ del árido, en una relación de volúmenes $1: 1$. Se obtuvieron siete mezclas, una de ellas compuesta sólo por cal y árido, que se tomó como grupo control. A las otras seis mezclas se añadió un almidón de patata comercial (PS), en diferentes cantidades. Las dosificaciones que se ensayaron fueron $0,03,0,06,0,15,0,30,0,50$, y $0,80 \%$ relativas al peso total del mortero seco, y para ello se siguieron las dosificaciones de otros reductores de agua y almidones referidas en la bibliografía $(9,10,13$, $14,30,31)$. Las muestras se han denominado, en función de la cantidad de aditivo antes reseñada, desde PS-1 a PS-6. El polímero lo aportó un fabricante de aditivos (OPAGEL CMT" AVEBE) que lo describe como almidón de patata natural modificado. Se llevó a cabo una comparación entre el aditivo y un almidón puro soluble (Merck, número de producto: 101252), encontrándose un gran parecido entre ambos (la Figura 1 muestra el espectro IR de ambos productos). La introducción de grupos funcionales para la obtención del aditivo prácticamente no origina modificaciones en el almidón de patata natural. and their grain size distribution have previously been reported (28). Mortars were prepared by mixing $341.7 \mathrm{~g}$ of the lime and $1286.9 \mathrm{~g}$ of the aggregate, amounting to a 1:1 volume ratio. Seven different dried mixtures were prepared. One of them was composed only of lime and aggregate, and was taken as a control mortar. A commercialized potato starch (PS) was incorporated into the other six mixtures, using a different dosage in each case. The proven dosages were $0.03,0.06,0.15,0.30$, 0.50 , and $0.80 \%$ of the total dried mortar's weight, according to dosages of other water reducers and starches $(9,10,13,14,30,31)$. Samples were named from PS-1 to PS-6 according to the amount of additive. The polymer was obtained from a supplier (OPAGEL $C M T "$ AVEBE) which describes it as a natural modified potato starch. A comparison between the admixture and a pure soluble starch (Merck, product number: 101252) was performed, showing a great similarity between the two (Figure 1 depicts the IR spectra of both products). Little modification, if any, was introduced to the natural potato starch with respect to the functional groups to obtain the additive.

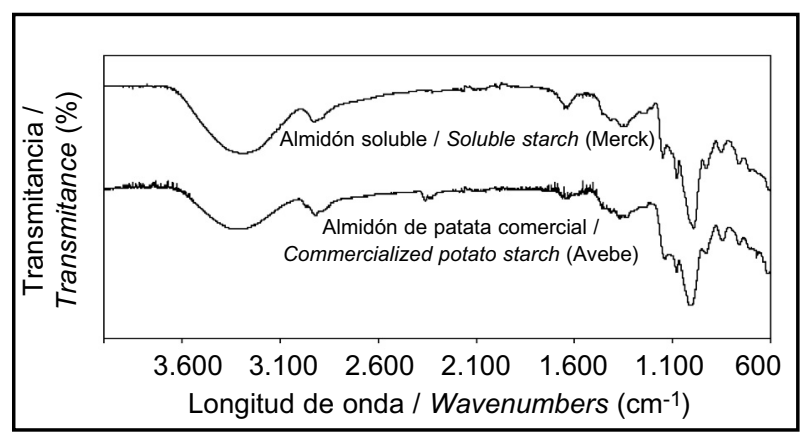

Figura 1. Espectro IR del almidón de patata comercial de Avebe y de almidón soluble de Merck.

Figure 1. IR spectra of commercialized potato starch from Avebe and soluble starch from Merck.

\subsection{Métodos}

\subsubsection{Preparación de los morteros}

Se estableció una relación agua/conglomerante de 1,2 con el criterio de obtener un material de referencia trabajable. Esta relación dio lugar a un valor de flujo en la mesa de sacudidas de $160 \pm 10 \mathrm{~mm}$. Con el fin de evaluar cualquier cambio causado por efecto del aditivo, se añadió esa misma cantidad de agua a todas las muestras, modificándose el escurrimiento en la mesa de sacudidas (Figura 2). A partir de estos datos, puede advertirse que la adición del almidón hasta un 0,30\% generó un efecto espesante, mientras que por encima de esa dosis, el aditivo comenzó a actuar como plastificante (con valor creciente del escurrimiento) (32). Se encontró también una relación entre las capacidades de retención de agua y la dosis del aditivo, de manera que sólo las dosificaciones más altas (en las que PS actúa como plastificante) dieron lugar a mayor capacidad de retención de agua (Figura 2) (32).

\subsection{Methods}

\subsubsection{Mortar preparation}

A water/binder ratio of 1.2 was set, according to the criterion of achieving a workable reference material. This relation matched a slump value of $160 \pm 10 \mathrm{~mm}$ when the flow table test was executed. In order to assess any change due to the performance of the admixture, the same amount of mixing water was incorporated for all the samples, thus modifying the flow table results (Figure 2). From these data, it can be seen that the starch addition up to $0.30 \%$ showed a thickening behaviour, while above that dosage, the admixture started acting as a plasticizer (with an increasing value of the slump) (32). Water retention capacities of the different mortars were also found to be related to the dosage of additive: only the highest dosages (where the $P S$ acted as a plasticizer) led to larger water retention capacities (Figure 2) (32). 


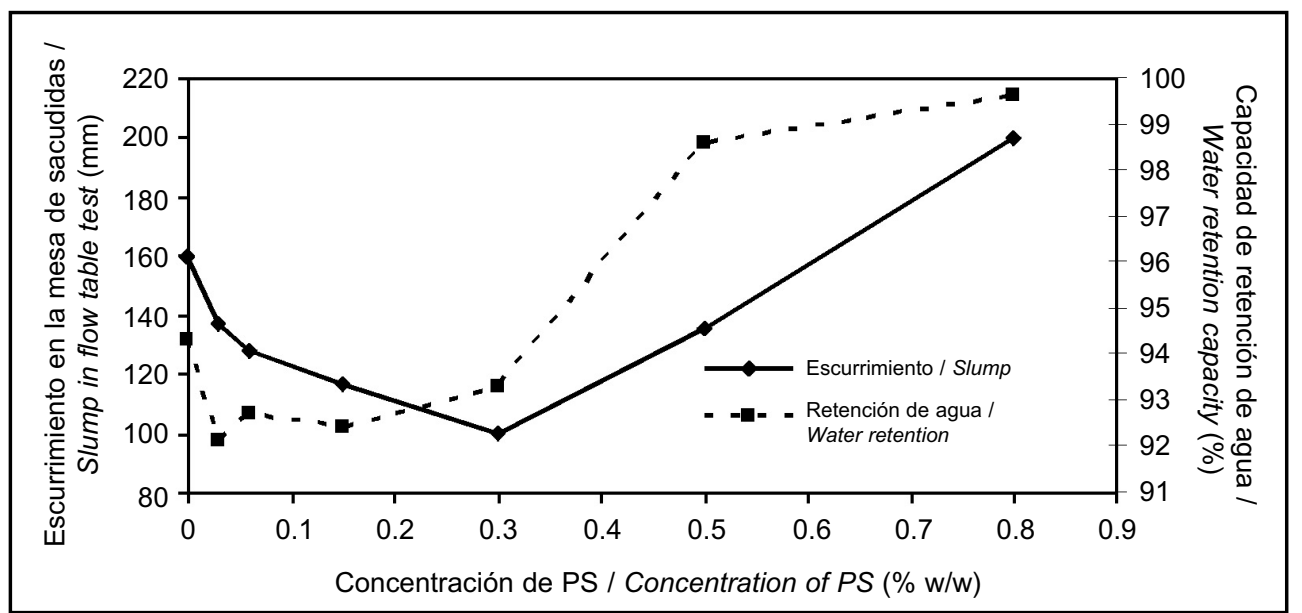

Figura 2. Resultados del escurrimiento en el test de la mesa de sacudidas y capacidad de retención de agua vs. concentración del almidón de patata.

Figure 2. Slump results in flow table test and water retention capacity vs. concentration of potato starch.

La cal, el árido y el aditivo PS, cuando se requería, se mezclaron durante 5 minutos en una mezcladora de aditivos en polvo BL-8-CA (Lleal S.A.). Después se añadió agua y mezcló durante 90 segundos a pocas revoluciones, en una amasadora Proeti ETI 26.0072. Los morteros así preparados se vertieron en moldes prismáticos de 40×40×160 mm y se desmoldaron 5 días después (34). Las mezclas frescas se compactaron en un dispositivo de compactación durante 60 segundos. El curado se realizó en condiciones de laboratorio durante 28 días (HR $60 \pm 10 \%$ y $20 \pm 5^{\circ} \mathrm{C}$ ). Se ensayaron 18 probetas, tres de cada mezcla.

Se llevaron a cabo análisis de densidad, retracción, absorción de agua por capilaridad (35), permeabilidad al vapor de agua (36), porosidad abierta, distribución de tamaño de poro (por porosimetría de intrusión de mercurio) y resistencias mecánicas (34). La durabilidad se estudió tras exposición a ciclos de hielo-deshielo.

\subsubsection{Densidad y retracción}

Las probetas se midieron con un calibre y pesado en una balanza METTLER PC 4000 para determinar su densidad, con carácter previo a los ensayos mecánicos. Tomando como referencia las dimensiones medidas al desmoldarlas, se pudo calcular la retracción.

\subsubsection{Capacidad de absorción de agua por capilaridad y permeabilidad al vapor de agua}

Las probetas utilizadas se prepararon de la misma forma que las empleadas para las determinaciones de las resistencias mecánicas. Tras los 28 días de curado en condiciones de laboratorio (HR $60 \pm 10 \%$ y $20 \pm 5^{\circ} \mathrm{C}$ ), se sellaron las cuatro caras principales de la probeta con parafina líquida. Cuando endureció la parafina, las probetas se
Lime, aggregate and PS, if necessary, were blended for 5 minutes using a solid mixer BL-8-CA (Lleal S.A.). Water was then added and mixed for 90 seconds at low speed, in a Proeti ETI 26.0072 mixer. Mortars were moulded in prismatic $40 \times 40 \times 160 \mathrm{~mm}$ casts and demolded 5 days later (34). Pastes were compacted in a specific device for 60 seconds. Curing was executed in laboratory conditions at room temperature for 28 days ( $R H 60 \pm$ $10 \%$ and $20 \pm 5^{\circ} \mathrm{C}$ ). Three specimens were prepared for each mixture; hence, 18 specimens were tested.

Analyses of density, shrinkage, water absorption through capillarity (35), water vapour permeability (36), open porosity, pore size distribution (by means of mercury intrusion porosimetry), and mechanical strengths (34) were carried out. Furthermore, durability was studied through freezing-thawing cycles.

\subsubsection{Density and shrinkage}

Before the specimens were broken during the mechanical test, their length was measured with a gauge and the mass was set with a balance METTLER PC 4000, which allowed us to determine their density. On the basis of the length that the samples showed when they were demolded, shrinkage could be calculated.

\subsubsection{Water absorption capacity through capillarity and water vapour permeability}

Samples used for the determination of water absorption capacity through capillarity were prepared in the same way as those for mechanical strengths tests. After 28 days of hardening in laboratory conditions at room temperature $\left(\mathrm{RH} 60 \pm 10 \%\right.$ and $\left.20 \pm 5^{\circ} \mathrm{C}\right)$, the four main surfaces of samples were covered with liquid 
rompieron en dos fragmentos y se pusieron en contacto con agua durante 90 minutos. La diferencia entre la masa inicial, la masa tras 10 minutos de inmersión y la masa tras 90 minutos permitió determinar el coeficiente de capilaridad (35).

Para estudiar la permeabilidad al vapor de agua se prepararon muestras específicas con forma de disco. Se curaron 28 días en condiciones de laboratorio y se colocaron a modo de tapas sobre recipientes que contenían solución saturada de $\mathrm{KNO}_{3}$. La pérdida de masa a lo largo de 72 horas permitió calcular la permeabilidad al vapor de agua de los morteros (36).

\subsubsection{Resistencias mecánicas}

Los ensayos de flexotracción se realizaron utilizando una prensa Frank/Controls 81565 a baja velocidad de carga $\left(10 \mathrm{~N} \cdot \mathrm{s}^{-1}\right)$. La resistencia a compresión se llevó a cabo en los dos fragmentos resultantes del test de flexotracción, en una prensa Proeti ETI 26.0052, con carga de $50 \mathrm{~N} \cdot \mathrm{s}^{-1}$ (34).

\subsubsection{Estructura porosa}

De acuerdo al test de saturación en agua (37), con una balanza hidrostática, se determinó la porosidad abierta. La distribución de tamaño de poro se llevó a cabo utilizando un equipo Micromeritics AutoPore IV 9500 con un rango de presión entre 0,0015 y $207 \mathrm{MPa}$, que registra automáticamente presión, diámetro de poro y volumen de intrusión.

\subsubsection{Durabilidad: ciclos de hielo-deshielo}

Debido a sus mejores resistencias mecánicas, se seleccionaron los morteros PS-5, sometiéndolos a ciclos de durabilidad y comparándolos con un grupo control. La preparación se realizó como se ha detallado en 3.2.1. El curado tuvo lugar en condiciones de laboratorio durante 56 días (HR $60 \pm 10 \%$ y $20 \pm 5^{\circ} \mathrm{C}$ ), y tras él, las muestras se sometieron a ciclos de hielo-deshielo. Se sumergieron en agua hasta saturación completa y después se congelaron en un arcón congelador (CARAVELL 521-102) a $-10^{\circ} \mathrm{C} \pm 2{ }^{\circ} \mathrm{C}$. Se prepararon diez probetas de cada mezcla, estudiándose un total de 20 morteros. Los días de ensayo se establecieron a 1, 4, 7, 10 y 14 ciclos completos. Se estudiaron la alteración cualitativa, de acuerdo a criterios previamente propuestos y publicados (38) y las resistencias a compresión. Cada día de ensayo se analizaron dos probetas de cada mortero, por lo que los resultados son una media entre los dos. La Tabla 1 muestra las características de los ciclos seguidos. paraffin to seal them. Once this had hardened, specimens were broken in two fragments, and these were immersed in water for 90 minutes. The difference between the initial mass, the mass after 10 minutes of immersion and the mass after 90 minutes made it possible to determine the capillarity coefficient (35).

Special samples disk-shaped were prepared to study the water vapour permeability of mortars. Specimens hardened for 28 days in laboratory conditions at room temperature, and were then placed as lids on containers where a saturated solution of $\mathrm{KNO}_{3}$ was put. The mass lost in the course of 72 hours permitted to calculate the water vapour permeability of mortars (36).

\subsubsection{Mechanical strengths}

The three-point flexural tests were carried out on the mortar specimens using a Frank/Controls 81565 compression machine at low rates of loading $\left(10 \mathrm{~N} \cdot \mathrm{s}^{-1}\right)$. Compressive strength tests were executed on the two fragments of each specimen resulting from the flexural tests. This was carried out on a Proeti ETI 26.0052, and the rate of loading was $50 \mathrm{~N} \cdot \mathrm{s}^{-1}$ (34).

\subsubsection{Pore structure}

Open porosity was determined according to the water saturation test (37) with a hydrostatic balance. The pore size distribution test was performed by using a Micromeritics AutoPore IV 9500 with a pressure range between 0.0015 and 207 MPa. Pressure, pore diameter and intrusion volume were automatically registered.

\subsubsection{Durability: Freezing-thawing cycles}

Owing to its better strength results, samples of PS-5 mortar were selected, prepared and subjected to durability cycles and compared to a control group. Mortars were prepared as explained above in 3.2.1. Curing was executed in laboratory conditions at room temperature over 56 days ( $R H 60 \pm 10 \%$ and $20 \pm$ $\left.5^{\circ} \mathrm{C}\right)$, and after that, samples were subjected to several freezing-thawing cycles. They were immersed in water until complete saturation and then frozen in a freezer (CARAVELL 521-102) at $\left(-10^{\circ} \mathrm{C} \pm 2^{\circ} \mathrm{C}\right)$. A total of ten specimens were prepared for each mixture; hence, 20 specimens were studied. Different testing days were set corresponding to $1,4,7,10$ and 14 complete cycles. Qualitative alteration according to a previously proposed criterion (38) and compressive strengths were studied. Two specimens of each mortar were tested at each point, and the reported results are an average of the two. Table 1 shows the characteristics of the set cycles. 
Tabla 1 / Table 1

Ciclos de hielo/deshielo.

Freezing-thawing cycles.

\begin{tabular}{|c|c|c|c|c|}
\hline $\begin{array}{c}\text { Duración del ciclo (horas) / } \\
\text { Cycle duration (hours) }\end{array}$ & Etapas / Steps & Temperatura / Temperature & $\begin{array}{c}\text { Inmersión en agua / } \\
\text { Water immersion }\end{array}$ & $\begin{array}{c}\text { Tiempo (horas) / } \\
\text { Time (hours) }\end{array}$ \\
\hline \multirow{2}{*}{48} & 1 & $\begin{array}{c}\text { Temperatura ambiente / } \\
\text { Room temperature }\end{array}$ & S í/ Yes & 24 \\
\cline { 2 - 5 } & 2 & $-10^{\circ} \mathrm{C} \pm 2^{\circ} \mathrm{C}$ & No & 24 \\
\hline
\end{tabular}

\section{RESULTADOS Y DISCUSIÓN}

\subsection{Densidad}

Como muestra la Tabla 2, la densidad en estado endurecido fue bastante similar para todos los morteros, aunque se pudo identificar una tendencia general, de manera que la densidad disminuyó al aumentar la cantidad de PS. La muestra PS-5 resultó ser una excepción, mostrando la mayor densidad en estado endurecido. Este hecho se ajustó a la evaluación visual de las muestras (Figura 3) y al cambio en la fluidez de las mismas (Figura 2). La defloculación que pudo observarse en la mezcla fresca de PS-5 dio lugar a una mayor coherencia en la pasta del mortero (Figura 3 a), reduciendo los espacios vacíos en el mortero endurecido, incrementando por tanto la densidad.

\section{RESULTS AND DISCUSSION}

\subsection{Density}

As Table 2 shows, the density at hardened state was quite similar for all the mortars, although it was possible to identify a general trend: density decreased as the amount of PS increased. PS-5 sample was an exception, showing the highest density at hardened state. This fact matched with the visual evaluation of the samples (Figure 3) and the change of fluidity behaviour (Figure 2). The deflocculation that could be observed in the fresh mixture of PS-5 gave rise to a greater coherence in the mortar paste (Figure 3 a), avoiding gaps in the hardened mortar, thus increasing the density.

Tabla 2 / Table 2

Densidad, retracción, coeficientes de capilaridad y permeabilidad, porosidad abierta en morteros endurecidos. Density, shrinkage, capillarity and permeability coefficients and open porosity at hardened state of the studied mortars.

\begin{tabular}{|c|c|c|c|c|c|}
\hline & $\begin{array}{l}\text { Densidad / Density } \\
(\mathrm{g} / \mathrm{mL})\end{array}$ & $\begin{array}{l}\text { Coeficiente de } \\
\text { retracción / Shrinkage } \\
\text { coefficient }(\mathrm{mm} / \mathrm{m})\end{array}$ & $\begin{array}{c}\text { Coeficiente de capilaridad / } \\
\text { Capillarity } \\
\text { coefficient }\left(\mathrm{kg} / \mathrm{m}^{2} \cdot \mathrm{min}^{1 / 2}\right)\end{array}$ & $\begin{array}{c}\text { Coeficiente de } \\
\text { permeabilidad / } \\
\text { Permeability coefficient }\end{array}$ & $\begin{array}{l}\text { Porosidad abierta I } \\
\text { Open porosity (\%) }\end{array}$ \\
\hline REF & 1.67 & 13.59 & 2.36 & 16.6 & 33.08 \\
\hline PS-1 & 1.60 & 13.33 & 2.52 & 12.5 & 31.28 \\
\hline PS-2 & 1.63 & 14.79 & 2.50 & 13.0 & 31.79 \\
\hline PS-3 & 1.61 & 16.35 & 2.36 & 11.8 & 31.50 \\
\hline PS-4 & 1.46 & 17.08 & 1.45 & 12.7 & 33.62 \\
\hline PS-5 & 1.68 & 25.63 & 1.85 & 19.1 & 28.36 \\
\hline
\end{tabular}

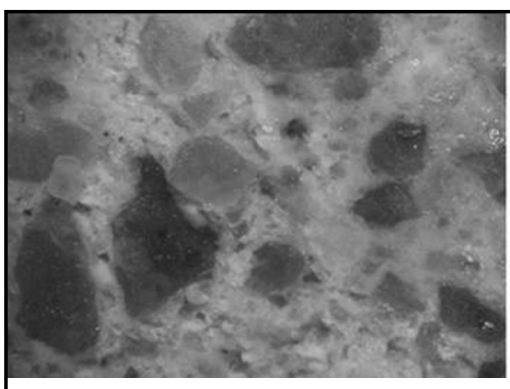

a)

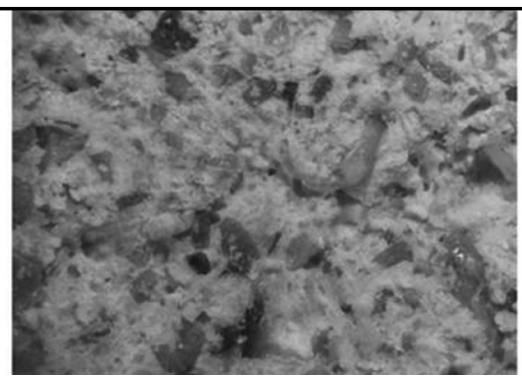

b)

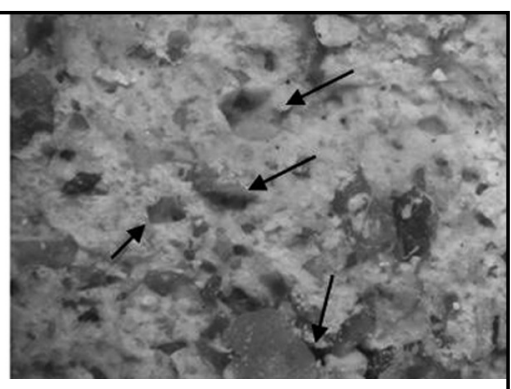

C)

Figura 3. Fragmentos de morteros endurecidos: a) muestra PS-5 a 16 aumentos, mostrando importante coherencia y escasa porosidad, b) mortero PS-4 a 16 aumentos, mostrando una matriz menos coherente, con mayor cantidad de poros y partículas del árido menos integradas; c) mortero PS-4 a 25 aumentos, donde se indican algunos poros visibles y algunos gránulos de árido se han desprendido claramente de la matriz.

Figure 3. Fragments of hardened mortars: a) PS-5 sample with a magnification of 16, showing large coherence and scarce porosity;

b) PS-4 mortar with a magnification of 16, showing a less coherent matrix, with larger amount of pores and less integrated aggregate particles; c) PS-4 mortar with a magnification of 25, where some visible pores have been marked and some aggregate grains are clearly disaggregated. 
Las propiedades en estado endurecido del mortero PS-6 no se midieron ya que presentó una naturaleza excesivamente líquida, lo que dificultó su manejo.

\subsection{Retracción}

Los coeficientes de retracción fueron muy altos, lo que, por otra parte, se esperaba al tratarse de morteros de cal (39). Algunos conglomerantes, cuando hay presentes en la mezcla algunos componentes absorbentes de agua, deben ser preparados con gran cantidad de agua de amasado. Ejemplos de este tipo de conglomerantes son los morteros de cal. Como resultado de la gran cantidad de agua de amasado, estos morteros sufren una considerable retracción $(40,41)$. Siguiendo esta tendencia, los coeficientes de retracción de los morteros aumentaron con la cantidad de aditivo (Tabla 2), y este hecho destacó especialmente en la muestra PS-5, que fue la que presentó mayor capacidad de retención de agua (Figura 2).

Gleen et al. (14) estudiaron la influencia de dos éteres de almidón diferentes como aditivos en hormigones ligeros. Encontraron que la gran capacidad de absorción de agua que los propios polímeros mostraron por sí mismos permitió reducir la cantidad de agua de amasado. Los aditivos fueron capaces de retener agua en su estructura, $y$, ya en la matriz del hormigón, pudieron transferirla al cemento dando lugar a una considerable retracción del polímero. En este estudio, el mortero PS-5 presentó una cantidad importante de almidón que le permitió retener agua y actuar conforme describieron Glenn et al. (14), contribuyendo al destacado coeficiente de retracción mostrado por esta mezcla.

\subsection{Capacidad de absorción de agua por capilaridad}

La absorción de agua es una propiedad de extrema importancia para morteros, que habitualmente son expuestos a los fenómenos ambientales -como lluviao están en contacto con elementos húmedos. Por ello, un mortero inadecuado podría sufrir daños y originar migraciones de agua dentro de la estructura del edificio, afectando perjudicialmente a otros materiales como las piedras, a través de fenómenos de eflorescencias (42).

Como muestra la Tabla 2, la adición del almidón redujo la capacidad de absorción de agua de los morteros sólo con grandes cantidades de aditivo (PS-4 y PS-5). La fuerza de absorción capilar (como diferencia de presión) se incrementa cuando el diámetro de poro disminuye (42). Evidentemente, la cantidad de poros de pequeño tamaño también juega un papel relevante. La gran compacidad del mortero PS-5 podría explicar su baja absorción de agua por capilaridad, ya que el número de poros en esta muestra debería ser menor que en las otras. El mortero
Hardened state properties of PS-6 mortar were not measured because it showed an excessively liquid nature which made it difficult to manipulate.

\subsection{Shrinkage}

As was expected for lime mortars, shrinkage coefficients were very high (39). Owing to the presence of some water-absorbent component, some binding materials must be prepared with large amount of mixing water. Lime mortars can be quoted as an example of this kind of material. As a result of the large amount of water, these mortars undergo considerable shrinkage $(40,41)$. Following this tendency, the shrinkage coefficients of the mortars rose with the amount of additive (Table 2), and this was especially important for PS-5, which was the mixture that showed the largest water retention capacity (Figure 2).

Gleen et al. (14) studied the influence of two different starch ethers as additives for lightweight concrete. They found that the large water absorption capacity, which these polymers showed in themselves, allowed them to reduce the amount of mixing water. The additives kept the water in their structure, and once in the concrete matrix, they could be transferred to the cement, giving rise to a considerable shrinkage of the polymer. In the present study, PS-5 mortar contained a large amount of starch which was able to retain water and could act as described by Glenn et al. (14), contributing to the outstanding shrinkage coefficient shown by this mixture.

\subsection{Water absorption capacity through capillarity}

Water absorption is an extremely important property for mortars, as they are usually exposed to environmental phenomena - such as rain - or in contact with elements that could be wet. As a consequence, an inappropriate mortar could become damaged and cause water movement inside the building structure, thus affecting and damaging other materials such as stones, through efflorescence phenomena (42).

As Table 2 shows, the addition of the starch reduced the water absorption capacity of the mortars only when the amount of admixture was high: PS-4 and PS-5 mortars. The capillary sorptivity force (as a pressure difference) increases when the pore diameter drops (42). Obviously, the amount of pores with small sizes also plays a relevant role. The great compaction of PS-5 mortar could explain its low water absorption capacity through capillarity, as the number of pores in this sample should be lower than those of other mixtures. PS-4-mortar 
PS-4 presentó una cantidad destacada de poros grandes (Figura 3b y 3c). Este hecho probablemente causó una disminución de los poros capilares, dando lugar a una caída en la succión capilar. El análisis de la estructura porosa de los morteros (4.2.6) será útil para confirmar estas suposiciones.

\subsection{Permeabilidad al vapor de agua}

El coeficiente de permeabilidad expresa la dificultad que las moléculas de vapor de agua encuentran al pasar a través de un mortero, por lo que, a menor coeficiente, mayor permeabilidad.

La Tabla 2 muestra los coeficientes de permeabilidad para las muestras analizadas. Puede verse que la adición de PS dio lugar a una mayor permeabilidad hasta el $0,30 \%$, mientras que la dosis más alta del aditivo produjo un notable descenso de esta propiedad. Los morteros hasta PS-4 mostraron menor coherencia (Figura 3b y $3 c)$, reflejada en valores más bajos de densidad, mientras que PS-5 se comportó de manera opuesta. Este cambio en la coherencia del material podría explicar la modificación en la permeabilidad al vapor de agua, dado que un material más coherente y compacto ofrecería mayor resistencia al paso de moléculas a través de él.

\subsection{Propiedades mecánicas}

La Figura 4 muestra los resultados de resistencia a la flexión y a la compresión para morteros estudiados tras 28 días de curado. Puede advertirse que la adición del almidón de patata condujo siempre a una mejora en las prestaciones mecánicas, excepto para la muestra PS-4. Además, la muestra PS-5 mostró una mejora sustancial en estas propiedades. showed an outstanding amount of large pores (Figure $3 b$ and 3c). This fact would probably cause a decrease in the amount of capillary pores, giving rise to a capillary suction drop. Analysis of the pore structure of mortars (4.2.6) will help to confirm these assumptions.

\subsection{Water vapour permeability}

The permeability coefficient expresses the difficulty that water vapour molecules find when trying to pass through a mortar, so the lower the coefficient, the higher the permeability.

Table 2 shows the permeability coefficients for the studied mortars. It can be seen that the addition of PS resulted in a larger permeability level of the material up to $0.30 \%$, while the highest dosage of admixture produced a huge decrease in this property. Mortars up to PS-4 showed lower coherence (Figure $3 b$ and 3c), reflected in lower density results, while PS-5 behaved in the opposite way. This change in the material's coherence could explain the modification in water vapour permeability, as a more coherent material will put up more resistance to the molecules that pass through it.

\subsection{Mechanical properties}

Figure 4 shows the flexural and compressive strength results for the mortars studied after 28 days of curing. It can be observed that the addition of potato starch always led to an improvement in mechanical properties, except for sample PS-4. Furthermore, PS-5 showed a great increase in those properties.

Leemann et al. (9) tested different viscosity modifiers - starch derivative being one of them - and stated that all

Leemann et al. (9) ensayaron diferentes modificadores de la viscosidad - un derivado de almidón entre ellos- y
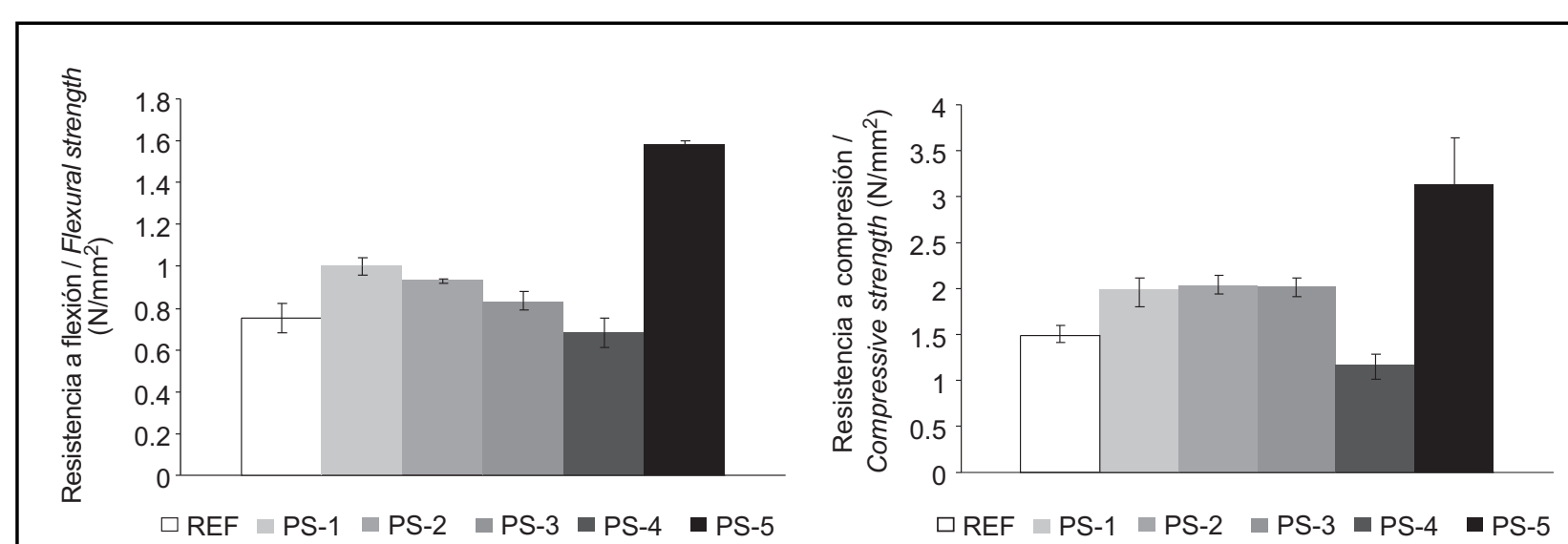

Figura 4. Resistencias a flexotracción y compresión a 28 días de curado para los morteros estudiados (se incluyen las barras de error). Figure 4. Flexural and compressive strengths after 28 days of hardening for the tested mortars (error bars are included). 
concluyeron que todos los morteros de cemento modificados con este tipo de aditivos mostraron mejores resistencias mecánicas que el mortero de referencia, debido a la mejora en la distribución del cemento en la masa. Fortes-Revilla et al. (31) concluyeron que un reductor de agua (basado en policarboxilato) mejoró las propiedades mecánicas finales de un mortero de cal-metacaolín, permitiendo además alcanzarlas antes. Identificaron como responsables de estos hechos a la baja porosidad y a la mayor cantidad de calcita.

La menor coherencia de PS-4, causada por el marcado efecto espesante del aditivo, dio lugar a la obtención de un material menos resistente. Por otra parte, la gran compacidad del mortero PS-5 originó una estructura coherente con un comportamiento mecánico muy mejorado (Figura 3a). Se considera también que la densidad de un mortero es uno de los factores con mayor influencia en sus prestaciones mecánicas: a medida que la densidad aumenta se mejora la resistencia (41). El efecto dispersante ejercido por el almidón de patata al incorporarlo en alta dosificación (0,50\%) podría explicar la mejor coherencia de la muestra PS-5, debido a la homogeneidad de la mezcla obtenida, como confirmaron los valores de densidad (Tabla 2). Este comportamiento coincide con los resultados publicados por Fortes-Revilla et al. (31).

La mejora en las propiedades mecánicas es un avance muy importante en morteros de cal, ya que una de sus principales desventajas son sus pequeñas resistencias -especialmente en comparación con las de los morteros de cemento- $(2,43)$.

La Figura 5 presenta resistencias a largo plazo para la muestra PS-5, demostrando que esta muestra dio lugar a mejor comportamiento mecánico que el mortero de control desde la primera semana de fraguado, especialmente en el test de flexión. Tras 28 días de curado, tanto la the cement mortars modified with this kind of admixture showed greater mechanical strengths than the reference mortar, due to the better cement distribution through the mass. Fortes-Revilla et al. (31) concluded that a water reducer (based on polycarboxylate) improved the final mechanical properties of lime-metakaolin mortar, and allowed them to be reached in a shorter period of time. They found the lower porosity and the larger amount of calcite to be responsible for this behaviour.

The lower coherence of PS-4, caused by the excessively marked thickening effect of the admixture, led to a weaker material. On the other hand, the great compaction of PS-5 mortar produced a coherent structure with a much improved mechanical behaviour (Figure 3a). The density of a mortar is supposed to be one of the most important factors affecting its mechanical performance: as the density increases, mechanical strengths improve (41). The dispersing effect that the potato starch exerted when used in large dosage $(0.50 \%)$ could explain the better coherence of PS-5 sample, due to the homogeneity of the obtained mixture, as the density values confirmed (Table 2). This behaviour matched the results obtained by Fortes-Revilla et al. (31).

The improvement in mechanical properties is a very important advance for lime-based mortars, due to the fact that the lower mechanical strengths that lime-based materials show - especially in comparison to the larger ones exhibited by cement mortars- is one of their main disadvantages $(2,43)$.

Figure 5 shows long-term strengths for the PS-5 sample, demonstrating that this sample presented better mechanical performance than the control mortar from the first week of setting, especially in the flexure test. After 28 days of setting, both flexural and

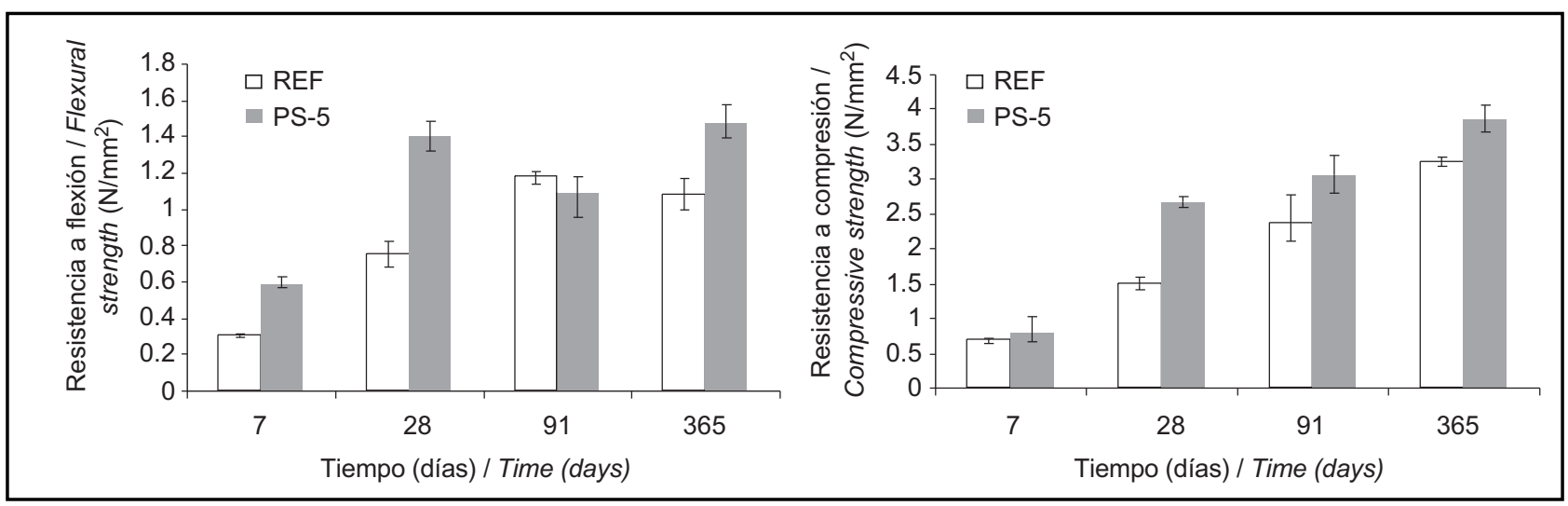

Figura 5. Resistencias a flexotracción y compresión del mortero PS-5 y de la muestra de referencia vs. tiempo (se incluyen las barras de error). Figure 5. Flexural and compressive strengths of PS-5 mortar and a reference sample vs. time (error bars are included). 
resistencia a la flexión como a la compresión ofrecieron valores que prácticamente doblaban a los valores de referencia. Tras un año de endurecimiento, ambas resistencias -a flexión y compresión- fueron mayores que las de la referencia. Como observación general, puede decirse que las resistencias más altas se alcanzaron en un periodo de tiempo considerablemente más corto, y que se vieron también mejoradas en ensayos a largo plazo. La misma conclusión obtuvieron Fortes-Revilla et al. (31) cuando incorporaron un reductor de agua tipo policarboxilato en morteros de cal-metacaolín. Relacionaron esto con la menor porosidad y mejor carbonatación de las muestras. En este estudio, el grado de carbonatación determinado fue similar para todas las muestras ensayadas (no se muestran resultados), pero la calcita podría estar mejor distribuida en la masa gracias a la mejor dispersión de la cal provocada por el aditivo, dando lugar a una estructura más uniforme con mejores propiedades mecánicas.

\subsection{Estructura porosa}

Pueden mencionarse diversos factores que influyen en la porosidad de un mortero, como: relación agua/conglomerante, las propiedades del conglomerante y del árido, las condiciones de curado y la presencia de aditivos (31, 44). En este trabajo, la dosificación del almidón de patata fue la única modificación introducida en los morteros objeto del estudio, por lo que las diferencias en el grado de porosidad entre ellos deben ser explicadas como consecuencia de la acción del aditivo.

Los resultados de porosidad abierta para los morteros endurecidos se muestran en la Tabla 2 . Como se observa, la adición de PS siempre condujo a menor porosidad, excepto en PS-4. La incorporación del aditivo hasta $0,30 \%$ originó un efecto espesante que derivó en una estructura más entrecruzada, con menor número de poros. La dosis de $0,30 \%$ espesó de tal manera la mezcla en fresco y creó tan gran número de aglomeraciones que, cuando el mortero se vertió en el molde, era muy poco fluido y no pudo ser adecuadamente compactado, originando gran cantidad de huecos (Figura 3b y 3c). La dosis más alta (muestra PS-5) conllevó un cambio en la acción del polímero, dando lugar a un efecto dispersante que originó una matriz más coherente y uniforme, permitiendo la consolidación de un material compacto, con muy pocos poros (Figura $3 a$ ). En consecuencia, la porosidad del mortero PS-5 fue la menor.

La Figura 6 contiene los resultados de la distribución de micro y mesoporos en los morteros objeto de estudio. El material de control presentó dos picos importantes, uno relacionado con poros grandes $(10 \mu \mathrm{m}$ y otro -el pico principal- relacionado con poros alrededor de $1 \mu \mathrm{m}$. Además, presentó cierta población de poros a $\sim 5 \mu \mathrm{m}$ compressive strengths were almost twice as much as the reference values. After one year of hardening, both flexural and compressive strength of PS-5 mortar were higher than the reference one. As a general observation, it can be said that final mechanical properties were reached in a considerable shorter period of time, and were also improved in long-term tests. The same conclusion was drawn by Fortes-Revilla et al. (31) when they incorporated a polycarboxylatetype water-reducing agent in lime mortars with metakaolin. They related this to the lower porosity and better carbonation of the samples. In the present study, the degree of carbonation was found to be similar for all the tested samples (results not shown), but calcite could be better distributed through the mass thanks to the better dispersion of the lime produced by the admixture, thus generating a more uniform structure with better mechanical properties.

\subsection{Pore structure}

There are several factors affecting the porosity of a mortar, such as: the water/binder ratio, the properties of the binder and the aggregate, the curing conditions and the presence of admixtures $(31,44)$. In the present study, the dosage of potato starch is the only modification introduced in the studied mortars, so differences in the porosity level between them must be explained in terms of the additive effect.

Open porosity results for hardened mortars are shown in Table 2. As can be observed, the addition of PS always led to a lower porosity level than the reference, except for PS-4. The incorporation of the additive up to $0.30 \%$ produced a thickening action which led to a more tangled structure, thus decreasing the number of pores. The dosage of $0.30 \%$ thickened the fresh mixture so greatly and created such a large number of agglomerates that, when the mortar was moulded, it was scarcely flowable and could not be properly compacted, generating a large amount of voids (Figure $3 b$ and $3 c$ ). The highest dosage (PS-5 sample) produced a change in the polymer behaviour, generating a dispersing effect which led to a more uniform and coherent matrix, and allowing the consolidation of a compact material, with few number of pores (Figure 3a). As a result, the porosity level of PS-5 mortar was the lowest.

Figure 6 shows the micro and meso-pore size distribution results for the studied mortars. The control material showed two important peaks: the first one was related to large pores $(10 \mu \mathrm{m})$ and the second one -which was the main peak- related to pores around $1 \mu \mathrm{m}$. Furthermore, it showed a certain population of pores at 


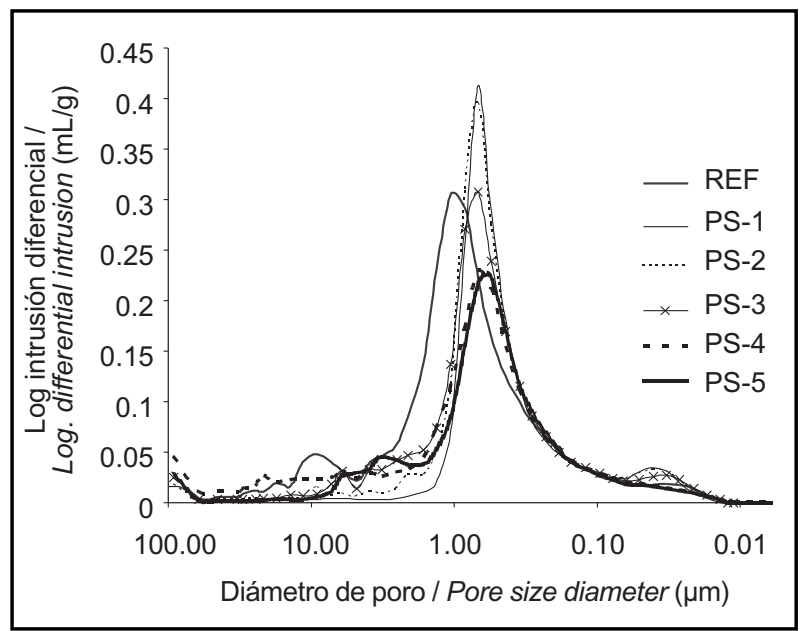

Figura 6. Distribución de tamaño de poro para los morteros estudiados.

Figure 6. Pore size distribution of the studied mortars.

(identificable como un hombro en el pico principal). La adición de PS derivó siempre en un descenso en el volumen intruido del pico a $10 \mu \mathrm{m}$, lo que podría estar relacionado con la acción espesante del polímero: su efecto floculante originó una estructura más entrecruzada, dando lugar a una reducción del tamaño de poro. Puede sugerirse que las diferencias en la distribución de poros entre la muestra PS-5 y las demás provienen de la macroporosidad, en lugar de la meso o micro-porosidad, como confirmaron los datos de porosidad abierta.

Teniendo en cuenta la porosidad y la distribución de tamaño de poro, los bajos coeficientes de capilaridad de las muestras PS-4 y PS-5 se explican por el hecho de que estas muestras presentaron la menor cantidad de poros de hasta $1 \mu \mathrm{m}$ (responsables de la absorción de agua por capilaridad).

Se ha señalado, de manera exhaustiva, que las propiedades mecánicas dependen estrechamente del grado de porosidad de los morteros: como criterio general, a mayor porosidad, menor resistencia $(2,31,44,45)$. La Figura 7 presenta la correlación entre la resistencia a compresión y la porosidad abierta de los morteros, mostrando cómo las $\sim 5 \mu \mathrm{m}$ (seen as a shoulder of the main peak). The addition of PS always led to a decrease in the intruded volume of the $10 \mu \mathrm{m}$ peak, which could be related to the thickening action of the polymer: its flocculation effect led to a more tangled structure, and so a pore size reduction took place. It may be suggested that differences in pore size distribution between PS-5 and the other samples arose from the macro-porosity level instead of the meso and micro-porosity ranges, as the open porosity results confirmed.

Taking into account the porosity as well as pore size distribution, the lowest capillarity coefficients of PS-4 and PS-5 samples can be explained by the fact that these samples presented the lowest amount of pores up to 1 $\mu m$ (responsible for the water absorption through capillarity).

Mechanical properties have been widely reported to be strongly dependent on the porosity level of the mortars: as a general statement, the larger the porosity, the lower the mechanical strengths $(2,31,44,45)$. Figure 7 presents the correlation between compressive strength and open porosity of mortars, showing that the

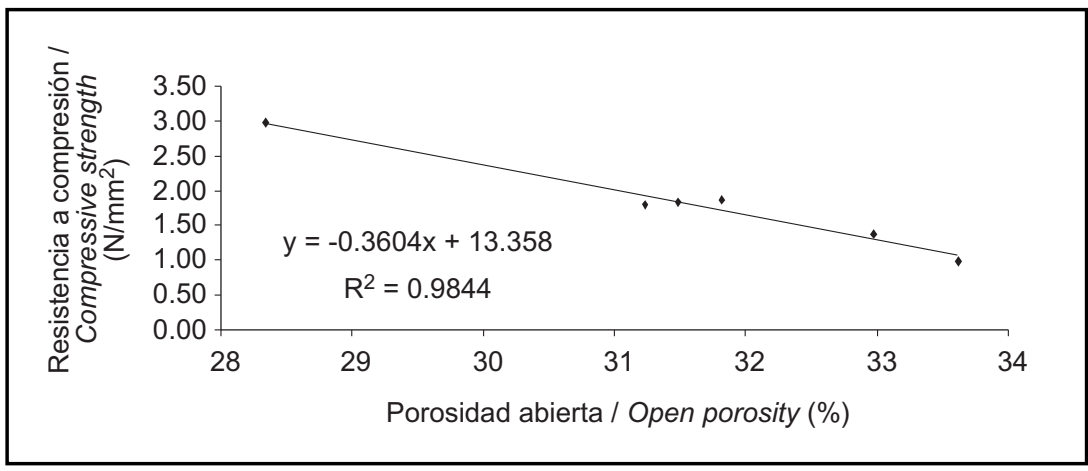

Figura 7. Relación entre la porosidad abierta y la resistencia a compresión para las muestras analizadas. Figure 7. Open porosity-compressive strength relationship for the studied mortars. 
diferencias en la porosidad abierta, dentro de los límites experimentales de este trabajo, podrían servir para explicar con facilidad el comportamiento mecánico observado.

\subsection{Durabilidad. Ciclos de hielo-deshielo}

En la Tabla 3 se recopilan los datos relativos al grado de alteración de los morteros tras haber sido sometidos a diversos ciclos de hielo-deshielo. Las probetas no soportaron todos los ciclos predeterminados. differences in open porosity, within the experimental limits of the present study, might easily serve to explain the observed mechanical behaviour.

\subsection{Durability: freezing-thawing cycles}

Table 3 shows the degree of alteration of the mortars after they were subjected to several freezing-thawing cycles. The specimens did not last long enough to be tested at all the set times.

Tabla 3 / Table 3

Evaluación cualitativa de los morteros durante los ciclos de hielo-deshielo. Qualitative evaluation of the mortars during freezing-thawing cycles.

\begin{tabular}{|c|c|c|c|}
\hline \multirow{2}{*}{} & \multicolumn{2}{|c|}{ Grado de alteración / Alteration degree } \\
\cline { 2 - 4 } & $\mathbf{1}$ ciclo / 1 cycle & 4 ciclos / 4 cycles & $\mathbf{7}$ ciclos / 7 cycles \\
\hline REF & 0 & 4 & - \\
\hline PS-5 & 0 & $1-2$ & $4-5$ \\
\hline
\end{tabular}

Equivalencias de los grados de alteración: / Equivalences of the alteration degrees:

0 : Sin alteración. / Without alteration.

1: Levemente alterado, algunas grietas pequeñas, cortas y finas, sobre la superficie de las muestras. / Slightly altered, some small (thin and short) cracks on the surface of the specimens.

2: Alterado, diversas fisuras (como en telaraña) más profundas. / Altered, several cracks (like spider's web) and deeper.

3: Muy alterado, varias grietas profundas y muestra hinchada. / Very altered, several deep cracks and swelling of the specimen.

4: Alto grado de alteración, grietas grandes y profundas, muestra muy hinchada incluyendo pérdidas de peso parcial. / High degree of alteration, large and deep cracks, large swelling of the specimen including a partial weight loss.

5: Completamente alterada, la muestra está prácticamente destruida, manteniéndose solo pequeñas partes de la misma. / Completely altered, the specimen is practically destroyed, only little pieces of it are kept.

El material de referencia quedó completamente destruido tras 6 ciclos de hielo-deshielo, y desde las primeras etapas mostró signos de deterioro (Figura 8). El mortero
The reference material was completely destroyed after 6 freezing-thawing cycles, and showed signs of deterioration from the first steps (Figure 8). PS-5 mortar showed much

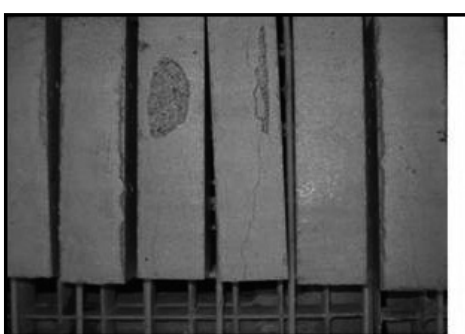

a)

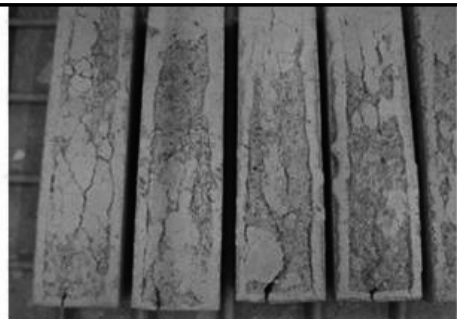

b)

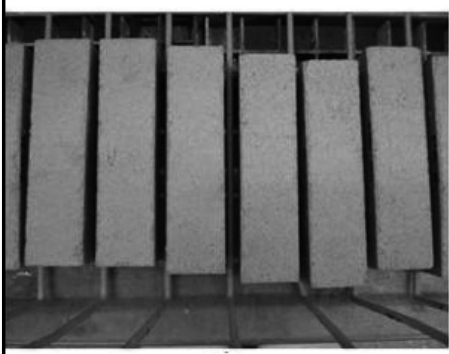

d)

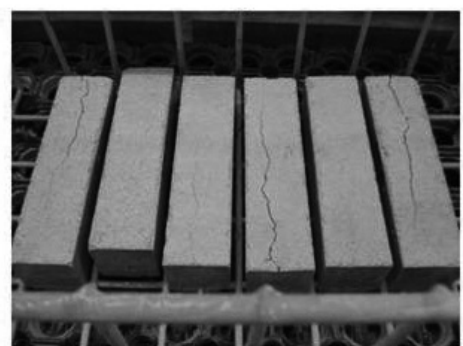

e
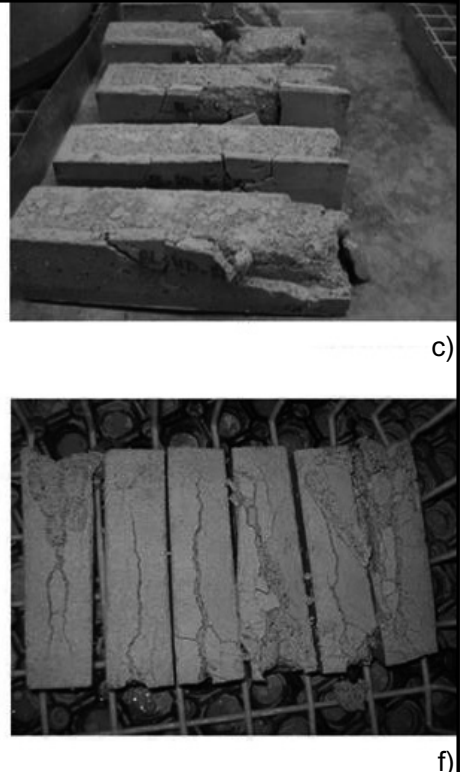

Figura 8. Muestras ensayadas tras ciclos de hielo-deshielo: a) probetas de la muestra REF tras 1 ciclo; b) probetas de la muestra REF tras 4 ciclos, con evidencias de alteración, c) muestras de REF tras 6 ciclos, completamente destruidas, d) probetas de la muestra PS-5 tras 1 ciclo; e) probetas de PS- 5 tras 4 ciclos, con pocas fisuras superficiales; f) probetas de PS- 5 destruidas tras el octavo ciclo. Figure 8. Tested specimens after freezing-thawing cycles; a) REF samples after 1 cycle; b) REF samples after 4 cycles, with evidences of alteration; c) REF samples after 6 cycles, totally destroyed; d) PS-5 specimens after 1 cycle; e) PS-5 specimens after 4 cycles, with few superficial cracks; $f$ ) destroyed PS-5 specimens during eighth cycle. 
PS-5 se comportó mucho mejor: no se originaron fisuras durante las primeras etapas $y$, solamente en algunas muestras, se apreció alteración visual tras cuatro ciclos. Las probetas se destruyeron por completo tras el octavo ciclo.

La Figura 9 presenta los resultados de resistencia a compresión de los materiales ensayados después de varios ciclos de hielo-deshielo. Puede observarse que el comportamiento mecánico del mortero PS-5 fue notablemente mejor que el del mortero de referencia. better performance: it did not show any crack during the first steps, and only some samples were visually affected after four cycles. Samples were destroyed during the eighth cycle.

Figure 9 presents the compressive strength results for the tested materials after they had been subjected to several freezing-thawing cycles. It can be observed that mechanical behaviour of PS-5 mortar was considerably better than that of the reference mortar.

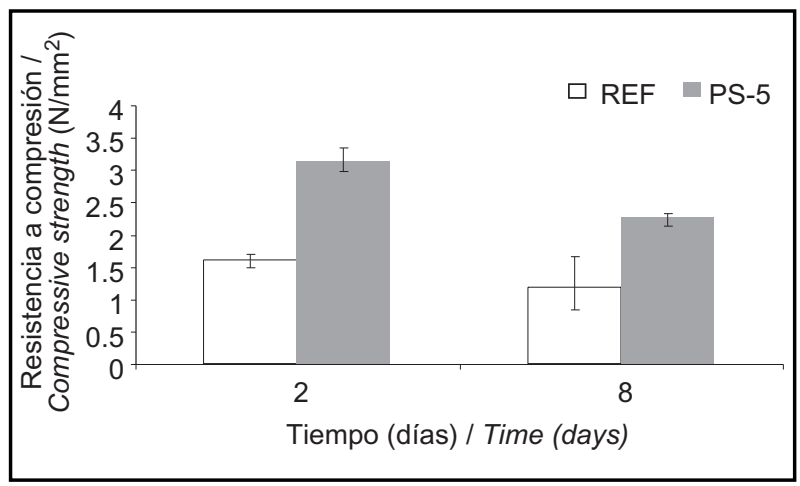

Figura 9. Resistencia a compresión de los morteros tras ciclos de hielo-deshielo (se incluyen las barras de error) Figure 9. Compressive strength of mortars after freezing-thawing cycles (error bars are included).

Esta mejora en la durabilidad del mortero PS-5 puede explicarse considerando su escasa absorción de agua por capilaridad así como su baja porosidad abierta. Dado que la estructura porosa del material dificultó la toma de agua, los procesos de hielo-deshielo le afectaron mucho menos, permitiéndole obtener mejor rendimiento en los tests de durabilidad. Debe señalarse que la bibliografía indica, como característica de gran importancia para morteros de reparación en trabajos de restauración, un adecuado comportamiento frente a ciclos de hielo-deshielo (46).

\section{CONCLUSIONES}

Se ensayó un almidón comercial (con diversas ventajas desde el punto de vista medioambiental en comparación con los plastificantes de tipo FDN y PC) como aditivo para morteros de cal aérea. Se añadieron distintas dosis del polímero a morteros estudiándose diversas propiedades en estado endurecido para comprobar su influencia en las propiedades finales del material.

Se encontró una dependencia íntima entre el comportamiento del aditivo y la dosis: actuó como espesante cuando la dosis resultó inferior al 0,30\% del total del mortero seco, generando una masa fresca más entrecruzada, que dio lugar a un material menos poroso una vez endurecido. Cuando se incorporó un 0,30\% de almidón,
The improvement in durability found for PS-5 mortar could be explained by considering its lower water absorption capacity through capillarity as well as its lower open porosity. As the pore structure of the material hindered the water intake, freezing and thawing processes affected the mortar in a less aggressive way, allowing to obtain better results in the durability test. The better performance of the modified lime mortar subjected to freezing-thawing cycles has been reported to be a relevant characteristic for repair mortar in restoration work (46).

\section{CONCLUSIONS}

A commercialized starch (with several environmental advantages compared to FDN and PC plasticizers) was tested as an additive for aerial lime-based mortars. Different dosages of the polymer were added to mortars and several properties at hardened state were studied in order to test their influence on the final material properties.

The behaviour of the admixture was found to be strongly dosage-dependent: it behaved as a thickener when the dosage was less than $0.30 \%$ of total dry mortar weight, generating a tangled fresh mass which led to a less porous hardened material. When $0.30 \%$ of starch was added, the large amount of polymer generated such a 
la mayor cantidad de polímero causó una cantidad tan grande de aglomerados de partículas que el mortero fresco apenas resultó trabajable y no se pudo compactar adecuadamente. Como consecuencia de ello, el grado de porosidad de la matriz aumentó, deteriorando las resistencias mecánicas. La dosis más alta de almidón $(0,50 \%)$ provocó un cambio en el comportamiento: ejerció un efecto dispersante que llevó a la obtención de una matriz más coherente y uniforme, consolidando un material compacto con menor porosidad. Debido a la densidad de su estructura, este mortero presentó un rendimiento muy satisfactorio: baja absorción de agua por capilaridad y pequeña permeabilidad al vapor de agua, resistencias mecánicas muy mejoradas desde los primeros días del fraguado y durabilidad frente a ciclos de hielo-deshielo incrementada. Además, las prestaciones mecánicas últimas se alcanzaron antes, lo que constituye una gran ventaja para morteros de cal.

Las mejoras descritas en este trabajo pueden ser de utilidad para obtener morteros de cal adecuados para su aplicación en trabajos de restauración y en obra nueva. Algunas de las principales desventajas que los materiales con base cal presentan (como las bajas resistencias mecánicas y el largo tiempo requerido para alcanzarlas) pueden ser resueltas con la incorporación del aditivo biodegradable ensayado, conduciendo a un producto final que, en cuanto a la cal, puede obtenerse de manera más respetuosa con el medio ambiente que los materiales basados en cemento, $y$, en cuanto al aditivo, presenta menor peligro a largo plazo para el entorno.

\section{AGRADECIMIENTOS}

Los autores desean agradecer a CTH Navarra y a Fernando Moreno (Calinsa, S.A., Navarra) el material suministrado para la realización de este trabajo. Igualmente, damos las gracias al personal del Laboratorio de Edificación (Universidad de Navarra) por su ayuda material, y a Jordi Sintes (AVEBE) por la información suministrada acerca de las características del aditivo. Este trabajo se ha desarrollado en el marco de un proyecto financiado por el Ministerio de Educación y Ciencia de España (MAT2007-65478) y por FUNA (Fundación Universitaria de Navarra). great amount of agglomerates that the fresh mortar became scarcely workable and could not be properly compacted. As a result, the porosity level of the hardened matrix increased, thus damaging the mechanical strengths. The highest dosage of starch $(0.50 \%)$ produced a change in the behaviour: it exerted a dispersing effect which led to a more uniform and coherent matrix, consolidating a compact material with a small number of pores. Owing to its dense structure, this mortar was found to have a very satisfactory performance: low water absorption capacity through capillarity and water vapour permeability, much improved mechanical strengths since the first days of setting and better durability results when subjected to freezing-thawing cycles. In addition, the final mechanical properties were reached sooner, which constitutes a great advantage for lime-based mortars.

The improvements described could be very useful to obtained appropriate lime-based mortars to apply in restoration work as well as for new building purposes. Some of the main disadvantages presented by lime materials (such as low mechanical strengths and the length of time required to reach them) can be resolved by the incorporation of the tested biodegradable additive, leading to a final product which can be produced in a more environmentally respectful way than cement-based materials, and which potentially presents less long-term danger to the environment.

\section{ACKNOWLEDGEMENTS}

The authors want to thank CTH Navarra and Fernando Moreno (Calinsa S.A. Navarra) for the material supplied. We are also grateful to the staff in Laboratorio de Edificación (Universidad de Navarra) for their material support and invaluable help, and to Jordi Sintes (AVEBE) for the information provided. This work was funded by the Ministry of Education and Science of Spain (MAT2007-65478) and FUNA (Fundación Universitaria de Navarra).

\section{BIBLIOGRAFÍA / BIBLIOGRAPHY}

(1) Sébaïbi, Y.; Dheilly, R. M.; Quéneudec, M.: "A study of the viscosity of lime-cement paste: influence of the physico-chemical characteristics of lime", Constr. Build. Mater., vol. 18 (2004), pp. 653-660. doi:10.1016/j.conbuildmat.2004.04.028

(2) Lanas, J.; Álvarez, J. I.: "Masonry repair lime-based mortars: Factors affecting the mechanical behaviour", Cem. Concr. Res., vol. 33 (2003), pp. 1867-1876. doi:10.1016/S0008-8846(03)00210-2

(3) Moropoulou, A.; Bakolas, A.; Moundoulas, P.; Aggelakopoulou, E.; Anagnostopoulou, S.: "Strength development and lime reaction in mortars for repairing historic masonries", Cem. Concr. Compos., vol. 27 (2005), pp. 289-294. doi:10.1016/j.cemconcomp.2004.02.017 
(4) Le Troëdec, M.; Peyratout, C. S.; Smith, A.; Chotard, T.: "Influence of various chemical treatments on the interactions between hemp fibres and a lime matrix", J. Eur. Ceram. Soc., vol. 29 (2009), pp. 1861-1868. doi:10.1016/j.jeurceramsoc.2008.11.016

(5) Zapata, A.; Bosch, P.: "Low temperature preparation of belitic cement clinker", J. Eur. Ceram. Soc., vol. 29 (2009), pp. 1879-1885. doi:10.1016/j.jeurceramsoc.2008.11.004

(6) Moropoulou, A.; Bakolas, A.; Aggelakopoulou, E.: "The effects of limestone characteristics and calcination temperature to the reactivity of the quicklime", Cem. Concr. Res., vol. 31 (2001), pp. 633-639. doi:10.1016/S0008-8846(00)00490-7

(7) Meier, A.; Bonaldi, E.; Cella, G. M.; Lipinski, W.; Wuillemin, D.; Palumbo, R.: "Design and experimental investigation of a horizontal rotary reactor for the solar thermal production of lime", Energy, vol. 29 (2004), pp. 811-821. doi:10.1016/S0360-5442(03)00187-7

(8) Rixom, R.; Mailvaganam, N.: Chemical admixtures for concrete., p. 213, E \& FN SPON, London, (1999). doi:10.4324/9780203017241

(9) Leeman, A.; Winnefeld, F.: "The effect of viscosity modifying agents on mortar and concrete", Cem. Concr. Res., vol. 29 (2007), pp. 341-349. doi:10.1016/j.cemconcomp.2007.01.004

(10) Zhang, D. F.; Ju, B. Z.; Zhang, S. F.; Yang J. Z.: "The study on the synthesis and action mechanism of starch succinate half ester as water-reducing agent with super retarding performance", Carbohydr. Polym., vol. 71 (2008), pp. 80-84. doi:10.1016/j.carbpol.2007.05.020

(11) Zhang, D. F.; Ju, B. Z.; Zhang, S. F.; He, L.; Yang, J. Z.: "The study on the dispersing mechanism of starch sulfonate as a waterreducing agent for cement", Carbohydr. Polym., vol. 70 (2007), pp. 363-368. doi:10.1016/j.carbpol.2007.04.024

(12) Peschard, A.; Govin, A.; Grosseau, P.; Guilhot, B.; Guyonnet, R.: "Effect of polysaccharides on the hydration of cement pastes at early ages", Cem. Concr. Res., vol. 34 (2004), pp. 2153-2158. doi:10.1016/j.cemconres.2004.04.001

(13) Vieira, M. C.; Klemm, D.; Einfeldt, L.; Albrecht, G.: "Dispersing agents for cement based on modified polysaccharides", Cem. Concr. Res., vol. 35 (2005), pp. 883-890. doi:10.1016/j.cemconres.2004.09.022

(14) Glenn, G. M.; Miller, R. M.; Orts, W. J.: "Moderate strength ligthweight concrete from organic aquagel mixtures", Ind. Crop. Prod., vol. 8 (1998), pp. 123-132. doi:10.1016/S0926-6690(97)10016-4

(15) Ouyang, X.; Jiang, X.; Qiu, X.; Yang, D.; Pang, Y.: "Effect of molecular weight of sulfanilic acid-phenol-formaldehyde condensate on the properties of cementitious system", Cem. Concr. Res., vol. 39 (2009), pp. 283-288. doi:10.1016/j.cemconres.2009.01.002

(16) Papo, A.; Piani, L.: "Effect of various superplasticizers on the rheological properties of Portland cement pastes", Cem. Concr. Res., vol. 34 (2004), pp. 2097-2101. doi:10.1016/j.cemconres.2004.03.017

(17) Fernandes, V.; Silva, L.; Ferreira, V. M.; Labrincha, J. A.: "Evaluation of mixing and application process parameters of single-coat mortars", Cem. Concr. Res., vol. 35 (2005), pp. 836-841. doi:10.1016/j.cemconres.2004.10.026

(18) Peschard, A.; Govin, A.; Pourchez, J.; Fredon, E.; Bertrand, L.; Maximilien, S.; Guilhot, B.: "Effect of polysaccharides on the hydration of cement suspension", J. Eur. Ceram. Soc., vol. 26 (2006), pp. 1439-1445. doi:10.1016/j.jeurceramsoc.2005.02.005

(19) Pourchez, J.; Govin, A.; Grosseau, P.; Guyonnet, R.; Guilhot, B.; Ruot, B.: "Alkaline stability of cellulose ethers and impact of their degradation products on cement hydration", Cem. Concr. Res., vol. 36 (2006), pp. 1252-1256. doi:10.1016/j.cemconres.2006.03.028

(20) Pourchez, J.; Peschard A.; Grosseau, P.; Guyonnet, R.; Guilhot, B.; Vallee, F.: "HPMC and HEMC influence on cement hydration", Cem. Concr. Res., vol. 36 (2006), pp. 288-294. doi:10.1016/j.cemconres.2005.08.003

(21) Jolicoeur, C.; Simard, M. A.: "Chemical admixture-cement interactions: phenomenology and physico-chemical concepts", Cem. Concr. Compos., vol. 20 (1998), pp. 87-101. doi:10.1016/S0958-9465(97)00062-0

(22) Lanas, J.; Pérez-Bernal, J. L.; Bello, M. A.; Álvarez, J. I.: "Mechanical properties of masonry repair dolomitic lime-based mortars", Cem. Concr. Res., vol. 36 (2006), pp. 951-960. doi:10.1016/j.cemconres.2005.10.004

(23) Lanas, J.; Pérez-Bernal J. L.; Bello, M. A.; Álvarez, J. I.: "Mechanical properties of natural hydraulic lime-based mortars", Cem. Concr. Res., vol. 34 (2004), pp. 2191-2201. doi:10.1016/j.cemconres.2004.02.005

(24) Arandigoyen, M.; Álvarez, J. I.: "Carbonation process in lime pastes with different water/binder ratio", Mater. Construcc., vol. 56 (2006), pp. 5-18.

(25) Arandigoyen, M.; Bicer-Simsir, B.; Álvarez, J. I.; Lange, D. A.: "Variation of microstructure with carbonation in lime and blended pastes", Appl. Surf. Sci., vol. 252 (2006), pp. 7562-7571. doi:10.1016/j.apsusc.2005.09.007

(26) Arandigoyen, M.; Álvarez, J. I.: "Pore structure and carbonation in blended lime-cement pastes", Mater. Construcc., vol. 56 (2006), pp. 17-30.

(27) Rodríguez-Navarro, C.; Ruiz-Agudo, E.; Ortega-Huertas, E.; Hansen, E.: "Nanostructure and irreversible colloidal behavior of $\mathrm{Ca}(\mathrm{OH}) 2$ : implications in cultural heritage conservation", Langmuir 2005; 21: 10948-10957. doi:10.1021/la051338f PMid:16285758

(28) Izaguirre, A.; Lanas, J.; Álvarez, J. I.: "Effect of water-repellent admixtures on the behaviour of aerial lime-based mortars", Cem. Concr. Res., vol. 39 (2009), pp. 1095-1104. doi:10.1016/j.cemconres.2009.07.026

(29) Izaguirre, A.; Lanas, J.; Álvarez, J. I.: "Ageing of lime mortars with admixtures: durability and strength assessment", Cem. and Concr. Res., vol. 40, (2010), pp. 1081-1095, 10.1016/j.cemconres.2010.02.013.

(30) Seabra, M. P.; Paiva, H.; Labrincha, J. A.; Ferreira, V. M.: "Admixtures effect on fresh state properties of aerial lime based mortars", Constr. Build. Mater., vol. 23 (2009), pp. 1147-1153. doi:10.1016/j.conbuildmat.2008.06.008

(31) Fortes-Revilla, C.; Martínez-Remírez, S.; Blanco-Varela, M. T.: "Modelling of slaked-lime metacaolín mortar engineering characteristics in terms of process variables", Cem. Concr. Compos., vol. 28 (2006), pp. 458-467. doi:10.1016/j.cemconcomp.2005.12.006 
(32) Izaguirre, A.; Lanas, J.; Álvarez, J. I.: "Behaviour of a starch as a viscosity modifier for aerial lime-based mortars", Carbohyd. Polym., vol. 80 (2010), pp. 222-228. doi:10.1016/j.carbpol.2009.11.010

(33) UNE 459-1, Building lime. Part 1. Definition, specification and conformity criteria (2001).

(34) UNE-EN 1015-11, Methods of test for mortar for masonry. Part 11: Determination of flexural and compressive strength of hardened mortar (2000).

(35) UNE-EN 1015-18, Methods of test for mortar for masonry. Part 18: Determination of water absorption coefficient due to capillary action of hardened mortar (2003).

(36) UNE-EN 1015-19, Methods of test for mortar for masonry. Part 19: Determination of water vapour permeability of hardened rendering and plastering mortars (1999).

(37) Rilem: "Recommended tests to measure the deterioration of stone and asses the effectiveness of treatment methods", Mater. Struct., vol. 13 (1980), pp. 175-253.

(38) Lanas, J.; Sirera, R.; Álvarez, J. I.: "Study of the mechanical behavior of masonry repair lime-based mortars cured and exposed under different conditions", Cem. Concr. Res., vol. 36 (2006), pp. 961-970. doi:10.1016/j.cemconres.2005.12.003

(39) Collins, F. G.; Sanjayan, J. G.: "Workability and mechanical properties of alkali activated slag concrete"; Cem. Concr. Res., vol. 29 (1999), pp. 455-458. doi:10.1016/S0008-8846(98)00236-1

(40) Mesbah, H. A.; Buyle-Bodin, F.: "Efficiency of polypropylene and metallic fibres on control of shrinkage and cracking of recycled aggregate mortars", Constr. Build. Mater., vol. 13 (1999), pp. 439-447. doi:10.1016/S0950-0618(99)00047-1

(41) Fernandes, V.; Silva, L.; Ferreira, V. M.; Labrincha, J. A.: "Influence of the kneading water content in the behaviour of single-coat mortars", Cem. Concr. Res., vol. 35 (2005), pp. 1900-1908. doi:10.1016/j.cemconres.2005.04.011

(42) Arandigoyen, M.; Pérez Bernal, J. L.; Bello López, M. A.; Álvarez, J. I.: "Lime-pastes with different kneading water: Pore structure and capillary porosity", Appl. Surf. Sci., vol. 252 (2005) pp. 1449-1459. doi:10.1016/j.apsusc.2005.02.145

(43) Billong, N.; Melo, U. C.; Njopwouo, D.; Louvet, F.; Bonnet, J. P.: "Effect of mixture constituents on properties of slaked lime-metakaolin-sand mortars containing sodium hydroxide", Cem. Concr. Compos., vol. 31 (2009), pp. 658-662. doi:10.1016/j.cemconcomp.2009.06.001

(44.) Papayianni, I.; Stefanidou, M.: "Strength-porosity relationships in lime-puzzolan mortars", Constr. Build. Mater., vol. 20 (2006), pp. 700-705. doi:10.1016/j.conbuildmat.2005.02.012

(45) Mosquera, M. J.; Benítez, D.; Perry, S. H.: "Pore structure in mortars applied on restoration. Effect on properties relevant to decay of granite buildings", Cem. Concr. Res., vol. 32 (2002), pp. 1883-1888. doi:10.1016/S0008-8846(02)00887-6

(46) Arıoglu, N.; Acun, S.: "A research about a method for restoration of traditional lime mortars and plasters: A staging system approach", Build. Environ., vol. 41 (2006), pp. 1223-1230. doi:10.1016/j.buildenv.2005.05.015 